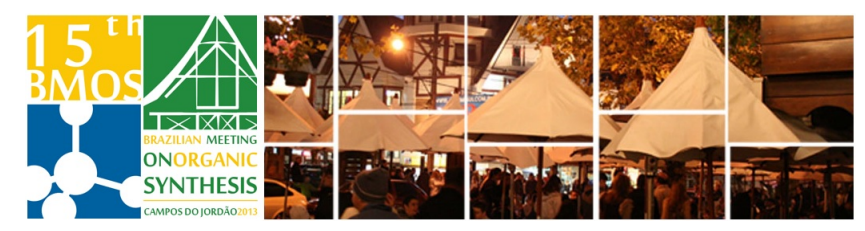

\title{
Synthesis of selenium linked steroidal glycoconjugates
}

\author{
Ricardo F. Affeldt ${ }^{\star 1}$, Letiére C. Soares, Oscar E. D. Rodrigues ${ }^{2}$ and Diogo S. Ludtke ${ }^{1}$ \\ 1. Instituto de Química, UFRGS, Porto Alegre, RS. 2. Depto. de Química, UFSM, Santa Maria, RS. Brazil. \\ *r.affeldt@gmail.com
}

Keywords: selenoglycosides, glycoconjugation, cholesterol

\section{INTRODUCTION}

Steroidal glycosides derivatives are found in several natural products and shows cardiotonic and anticancer activity, such as diosgine and digitoxin. ${ }^{1}$ On the other hand, selenoglycosides have been explored as potential anti-HIV, anticancer and antioxidants. ${ }^{2}$ We have recently described the synthesis of selenium linked carbohydrate and amino acid glycoconjugates. ${ }^{3}$ In this work we synthesized cholesterol Se-glycoconjugates by selective ring opening of cholesterol epoxide.

\section{RESULTS AND DISCUSSION}

Initially were obtained glycosyl diselenides 2 from $D$ galactose, $D$-ribose and $D$-xylose in 3 steps in 82$90 \%$ yield, by reacting sugar-protected tosylates 1 with $\mathrm{Li}_{2} \mathrm{Se}_{2}$ (figure 1). The cholesterol epoxides 3 were obtained by a previously optimized methodology involving asymmetric epoxidation of a double bound. ${ }^{4}$

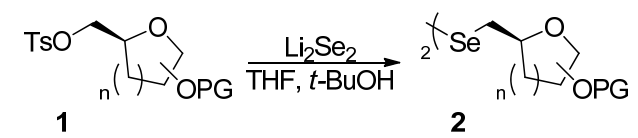

Figure 1. Synthesis of carbohydrate diselenides

We then explored the selenium linkage of the two structures with reductive cleavage of the diselenide derived from $D$-galactose to provide the nucleophilic cholesterol epoxide opening. After the in situ formation of the nucleophilic selenocarbohydrate specie by reaction with a suitable reductant agent in inert atmosphere it was added a solution of the cholesterol. The best yields were obtained after $48 \mathrm{~h}$ in THF/EtOH or DMF (Table 1, entries 2 and 3). Changing the reducing agent furnished lower yields as well as addition of $\mathrm{ZnCl}_{2}$ catalyst (entries 8-10).

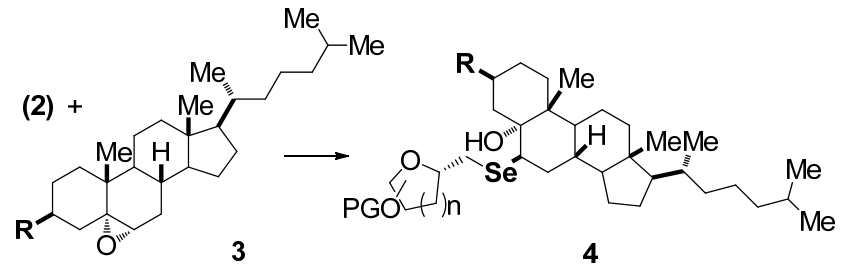

Figure 2. Synthesis of steroidal selenoglycoconjugates
Table 1. Reaction between 1:1.8 eqv. of 2 and $\mathbf{3}$

\begin{tabular}{|c|c|c|c|c|c|c|}
\hline$\#$ & $\mathbf{R}$ & $\begin{array}{c}\text { Reducing } \\
\text { agent }\end{array}$ & Solvent & $\begin{array}{c}\mathbf{T} \\
\left({ }^{\circ} \mathbf{C}\right)\end{array}$ & $\begin{array}{c}\mathbf{t} \\
(\mathbf{h})\end{array}$ & $\begin{array}{c}\text { Yield } \\
(\%)\end{array}$ \\
\hline 1 & $\mathrm{OH}$ & $\mathrm{NaBH}_{4}$ & $\mathrm{THF} / \mathrm{EtOH}$ & 66 & 24 & 37 \\
\hline 2 & $\mathrm{OH}$ & $\mathrm{NaBH}_{4}$ & $\mathrm{THF} / \mathrm{EtOH}$ & 66 & 48 & 65 \\
\hline 3 & $\mathrm{OH}$ & $\mathrm{NaBH}_{4}$ & $\mathrm{DMF}$ & 80 & 48 & $60^{*}$ \\
\hline 4 & $\mathrm{OH}$ & $\mathrm{NaBH}_{4}$ & $\mathrm{DMF}$ & 120 & 48 & 53 \\
\hline 5 & $\mathrm{OH}$ & $\mathrm{NaBH}_{4}$ & EtOH & 76 & 48 & 50 \\
\hline 6 & $\mathrm{OMe}$ & $\mathrm{NaBH}_{4}$ & DMF & 80 & 48 & 45 \\
\hline 8 & $\mathrm{OH}$ & $\mathrm{NaBH}_{4}$ & THF/EtOH & 66 & 48 & $5 \%{ }^{* *}$ \\
\hline 9 & $\mathrm{OH}$ & $\mathrm{LiAlH}_{4}$ & THF/EtOH & 80 & 48 & $5 \%$ \\
\hline 10 & $\mathrm{OH}$ & $\mathrm{LiEt}_{3} \mathrm{BH}$ & THF & 66 & 48 & $50 \%$ \\
\hline
\end{tabular}

${ }^{*} 1: 1$ diselenide:epoxide; ${ }^{* *} 1$ eqv. of $\mathrm{ZnCl}_{2}$

We choose to explore the scope of the reaction with equimolar mixture of the diselenide and the epoxide in DMF at $80^{\circ}$ for $48 \mathrm{~h}$ with $\mathrm{NaBH}_{4}$ changing the sugar from $D$-galactose to $D$-ribose diselenide, were similar yields were obtained (figure 3 ).

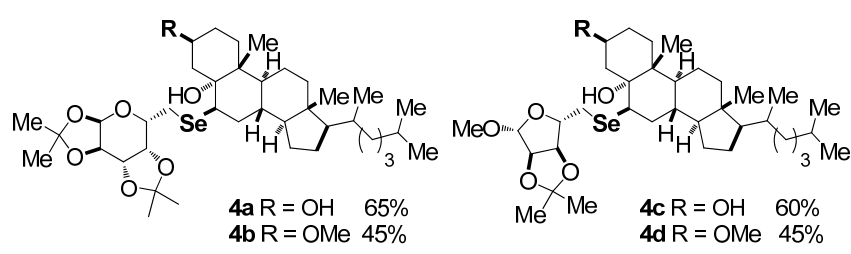

Figure 3. Steroidal selenoglycoconjugates.

\section{CONCLUSION}

It was successfully achieved steroidal selenoglycoconjugates in a convergent and stereoselective synthesis and modification of both sugar and cholesterol units are under investigation. The new compounds posses high molecular complexity and potential biological activity.

\section{ACKNOWLEDGEMENTS}

CNPq, FAPERGS and CAPES.

\section{REFERENCES}

Jensen, M.; Schmidt, S.; Fedosova, N. U.; Mollenhauer, J.; Jensen, H. H. Bioorg. Med. Chem. 2011, 19, 2407.

2 (a) Boutureira, O.; Bernardes, G. J. L.; Fernandez-Gonzalez, M.; Anthony, D. C.; Davis, B. G. Angew. Chem. Int. Ed. 2012, 51, 1432. (b) Vargas, L. M.; Soares, M. B.; Izaguirry, A. P.; Lüdtke, D. S.; Braga, H. C.; Savegnago, L.; Wollenhaupt, S.; Brum, D. S.; Leivas, F. G.; Santos, F. W. J. App. Toxicol. 2013, 33, 679 .

${ }^{3}$ Affeldt, R. F.; Braga, H. C.; Baldassari, L. L.; Lüdtke, D. S. Tetrahedron, 2012, 68, 10470.

${ }^{4}$ Rodrigues, O. E. D.; Souza, D.;.Soares, L. C.; Dornelles, L.; Burrow, R. A.; Appelt, H. R.; Alves, C. F.; Alves, D.; Braga, A. L. Tetrahedron Lett. 2010, 51, 2237. 